Received 6 January; accepted 18 February 1997.

1. Chrivia, J. C. et al. Phosphorylated CREB binds specifically to the nuclear protein CBP. Nature 365, 855-859 (1993).

Kwok, R. P. S. et al. Nuclear protein CBP is a coactivator for the transcription factor CREB. Nature 370, 223-226 (1994)

3. Arias, J. et al. Activation of cAMP and mitogen-responsive genes relies on a common nuclear factor. Nature 370, 226-229 (1994)

4. Bannister, A. J. \& Kouzarides, T. CBP-induced stimulation of c-Fos activity is abrogated by E1A. EMBO J. 14, 4758-4762 (1995).

Kamei, Y. et al. A CBP integrator complex mediates transcriptional activation and AP-1 inhibition by nuclear receptors. Cell 85, 403-414 (1996).

6. Dai, P. et al. CBP as a transcriptional coactivator of c-Myb. Genes Dev. 10, 528-540 (1996).

Bhattacharya, S. et al. Cooperation of Stat 2 and p300/CBP in signalling induced by interferon- $\alpha$. Nature 383, 344-347 (1996).

8. Petrij, F. et al. Rubinstein-Taybi syndrome caused by mutations in the transcriptional co-activator CBP. Nature 376, 344-347 (1996)

9. Orenic, T. V., Slusarski, D. C., Kroll, K. L. \& Holmgren, R. A. Cloning and characterization of the segment polarity gene cubitus interruptus dominant of Drosophila. Genes Dev. 4, 1053-1067 (1990).

10. Blair, S. S. Hedgehog digs up an old friend. Nature 373, 656-657 (1995).

11. Hui, C.-C. \& Joyner, A. L. A mouse model of Greig cephalopolysyndactyly syndrome: the extra-toes mutation contains an intragenic deletion of the Gli3 gene. Nature Genet. 3, 241-245 (1993).

12. Vortkamp, A., Gessler, M. \& Grzeschik, K.-H. GLI3 zinc-finger gene interrupted by translocations in Greig syndrome families. Nature 352, 539-540 (1991)

13. Alexandre, C., Jacinto, A. \& Ingham, P. W. Transcriptional activation of hedgehog target genes in Drosophila is mediated directly by the Cubitus interruptus protein, a member of the GLI family of zinc finger DNA-binding proteins. Genes Dev. 10, 2003-2013 (1996).

14. Locke, J. \& Tartof, K. D. Molecular analysis of cubitus interruptus (ci) mutations suggests an explanation for the unusual $c i$ position effects. Mol. Gen. Genet. 243, 234-243 (1994).

15. Slusarski, D. C., Motzny, C. K. \& Holmgren, R. Mutations that alter the timing and pattern of cubitus interruptus gene expression in Drosophila melanogaster. Genetics 139, 229-240 (1995)

16. Schuske, K., Hooper, J. E. \& Scott, M. P. patched overexpression causes loss of wingless expression in Drosophila embryos. Dev. Biol. 164, 300-311 (1994).

17. Dominguez, M., Brunner, M., Hafen, E. \& Basler, K. Sending and receiving the hedgehog signal: control by the Drosophila Gli protein cubitus interruptus. Science 272, 1621-1625 (1996).

18. Hama, C., Ali, Z. \& Kornberg, T. B. Region-specific recombination and expression are directed by portions of the Drosophila engrailed promoter. Genes Dev. 4, 1079-1093 (1990).

19. Brown, N. H. \& Kafatos, F. C. Functional cDNA libraries from Drosophila embryos. J. Mol. Biol. 203, 425-437 (1988).

20. Johnson, R. L., Grenier, J. K. \& Scott, M. P. patched overexpression alters wing disc size and pattern transcriptional and post-transcriptional effects on hedgehog targets. Development 121, 4161-4170 (1995).

21. Tabata, T. \& Kornberg, T. B Hedgehog is a signaling protein with a key role in patterning Drosophila imaginal discs. Cell 76, 89-102 (1994).

22. Xu, T. \& Rubin, G. M. Analysis of genetic mosaics in developing and adult Drosophila tissues. Development 117, 1223-1237 (1993)

23. Vojtek, A. B., Hollenberg, S. M. \& Cooper, J. A. Mammalian ras interacts directly with the serine/ threonine kinase raf. Cell 74, 205-214 (1993).

24. Krasnow, M. A., Saffman, E. E., Kornfeld, K. \& Hogness, D. S. Transcriptional activation and repression by Ultrabithorax proteins in cultured Drosophila cells. Cell 57, 1031-1043 (1989).

25. Thummel, C. S., Boulet, A. M. \& Lipshitz, H. D. Vectors for Drosophila P-element-mediated transformation and tissue culture transfection. Gene 74, 445-456 (1988).

Acknowledgements. We thank J. Locke for $c i$ cDNA, fly stocks and helpful comments; R. Evans for the alcohol dehydrogenase promoter construct; T. Tabata, T. Kornberg and C. Hama for fly stocks; and Ministry of Education, Science and Culture of Japan to S.I., from the NIH to R.H.G., and from Human Frontiers to S.M.S.

Correspondence and requests for materials should be addressed to S.I. (sishii@rtc.riken.go.jp) or R.H.G. (goodmanr@ohsu.edu). The GenBank accession number for the dCBP cDNA sequence is U88570.

\section{Evidence for life on Earth before 3,800 million years ago}

\author{
S. J. Mojzsis, G. Arrhenius, K. D. McKeegan, \\ T. M. Harrison, A. P. Nutman \& C. R. L. Friend
}

Nature 384, 55-59 (1996)

The model calculation presented in this Letter is corrected by Eiler et al. in Scientific Correspondence elsewhere in this issue ${ }^{1}$.

1. Eiler, J. M., Mojzsis, S. J. \& Arrhenius, G. Carbon isotope evidence for early life. Nature 386, 665 (1997).

\section{erratum}

\section{Cloning of a disintegrin metalloproteinase that}

processes precursor tumour-necrosis factor- $\alpha$

Marcia L. Moss, S.-L. Catherine Jin, Marcos E. Milla, D. Mark Bickett, William Burkhart, H. Luke Carter, Wen-Ji Chen, William C. Clay, John R. Didsbury, Daniel Hassler, Christine R. Hoffman, Thomas A. Kost, Millard H. Lambert, M. Anthony Leesnitzer, Philip McCauley, Gerard McGeehan, Justin Mitchell, Mary Moyer, Gregory Pahel, Warren Rocque, Laurie K. Overton, Frank Schoenen, Theresa Seaton, Jui-Lan Su, Janet Warner, Derril Willard \& J. David Becherer

Nature 385, 733-736 (1997)

The fourth author's name (D.M.B.) was accidentally omitted; he is in the Department of Molecular Biochemistry at Glaxo Wellcome Research and Development.

Also, reference 8 was not included in the list. This was by G. M. McGeehan et al., "Regulation of tumour-necrosis factor- $\alpha$ processing by a metalloproteinase inhibitor", published in Nature 370, 558-561 (1994).

Stochastic resonance in non-dynamical systems without response thresholds

\section{Sergey M. Bezrukov \& Igor Vodyanoy}

Nature 385, 319-321 (1997).

A typographical error was introduced into equation (8) which is correct as shown here

$$
\mathrm{SNR}=\frac{\frac{V_{\mathrm{S}}^{2} r(0)}{2 \Delta f_{\mathrm{A}}} \exp \left(\frac{\sigma^{2}}{2}\right)}{2+\frac{r(0)}{f_{\mathrm{c}}} \sigma^{2} \exp \left(\frac{\sigma^{2}}{2}\right) \sum_{1}^{\infty} \frac{\sigma^{2 n-2}}{n ! n}}
$$

